\title{
Effects of high hydrostatic pressure on the structure of bovine $\alpha$-lactalbumin
}

\author{
J. O. Rodiles-López, ${ }^{*}$ I. J. Arroyo-Maya, ${ }^{*}$ M. E. Jaramillo-Flores, ${ }^{*}$ G. F. Gutiérrez-López, ${ }^{*}$ \\ A. Hernández-Arana, $\dagger$ G. V. Barbosa-Cánovas, $\ddagger$ K. Niranjan, $§$ and H. Hernández-Sánchez ${ }^{* 1}$ \\ *Departamento de Graduados e Investigación en Alimentos, Escuela Nacional de Ciencias Biológicas, Instituto Politécnico Nacional, \\ Carpio y Plan de Ayala, CP. 11340, México, DF, México \\ †Departamento de Química, Universidad Autónoma Metropolitana, Unidad Iztapalapa, México, DF, México \\ ‡Department of Biological Systems Engineering, Washington State University, Pullman 99164-6120 \\ $\S S c h o o l$ of Food Biosciences, University of Reading, Reading, United Kingdom
}

\begin{abstract}
The effects of high hydrostatic pressure (HHP) processing (at 200 to $600 \mathrm{MPa}, 25$ to $55^{\circ} \mathrm{C}$, and from 5 to $15 \mathrm{~min}$ ) on some structural properties of $\alpha$-lactalbumin was studied in a $\mathrm{pH}$ range of 3.0 to 9.0. The range of HHP processes produced a variety of molten globules with differences in their surface hydrophobicity and secondary and tertiary structures. At $\mathrm{pH}$ values of 3 and 5 , there was a decrease in the $\alpha$-helix content concomitant with an increase in $\beta$-strand content as the pressure increased. No changes in molecular size due to HHP-induced aggregation were detected by sodium dodecyl sulfate-PAGE. All samples showed higher thermostability as the severity of the treatment increased, indicating the formation of a less labile structure related to the HHP treatment.
\end{abstract}

Key words: $\alpha$-lactalbumin, high hydrostatic pressure, molecular property, protein structure

\section{INTRODUCTION}

The processes in which products are submitted to pressures from 200 to $800 \mathrm{MPa}$ are known as high hydrostatic pressure (HHP) technologies. In general, the process is batch operated and applied to several liquid and semisolid prepacked foods and food ingredients. High-pressure processing is carried out in 3 steps as follows: an initial period required for reaching the treatment pressure or come-up time, the time of processing at the desired pressure or holding time, and finally, a short time necessary for releasing the pressure or release time (Hogan et al., 2005). Such HHP processes are very effective for inactivation of vegetative microorganisms but less effective for certain bacterial spores and some enzymes (Devlieghere et al., 2004).

Received October 1, 2009.

Accepted December 24, 2009.

${ }^{1}$ Corresponding author: hhernan1955@yahoo.com
In the case of proteins, it has been reported that covalent bonds are not affected by HHP, thus maintaining intact primary structure under normal HHP operating conditions. However, secondary, tertiary, and quaternary structures are affected to different extents. In the range of 100 to $300 \mathrm{MPa}$, these changes are reversible, but pressures $>300 \mathrm{MPa}$ can bring on irreversible denaturation (Rastogi et al., 2007). Very high pressures $(>700 \mathrm{MPa})$ can induce irreversible denaturation by disrupting the secondary structure of the proteins (Balny and Masson, 1993). Tertiary structure undergoes changes at pressures $>200 \mathrm{MPa}$ because of alterations in hydrophobic and ionic bonds, whereas quaternary structure, which depends on noncovalent unions, is affected by pressures of 100 to $150 \mathrm{MPa}$ (Huppertz et al., 2004). These changes in the protein structure have profound effects on a protein's functionality and on its possible food applications (Krešić et al., 2006). In general, HHP-induced changes in proteins are dependent on additional parameters such as temperature, $\mathrm{pH}$, the solvent used for processing, and the final state of the protein preparation (Nabhan et al., 2004).

Whey proteins have been used as food ingredients because of their functional properties, and HHP-induced changes may improve these properties for different applications in the food industry (López-Fandiño, 2006). $\alpha$-Lactalbumin is one of the main components of whey protein, and its role in lactose biosynthesis is well documented. The concentration of $\alpha-\mathrm{LA}$ in cow milk varies from 1.2 to $1.5 \mathrm{~g} / \mathrm{L}$, and it is the second largest component by concentration (20\%) in the whey protein fraction after $\beta$-LG. $\alpha$-Lactalbumin has 4 intramolecular disulfide bonds with no free thiol groups (Farrell et al., 2004) and shows the best characterized molten globule (MG) state, which is highly stable and is therefore a favorite model for studying the folding of proteins. The MG is the partially folded state of a protein that resembles the intermediate structure formed during the protein folding process. These MG are also referred to as proteins in a semidenatured state. $\alpha$-Lactalbumin can form $\mathrm{MG}$ under different conditions, including a low $\mathrm{pH}$ 
Table 1. Box-Behnken 3-level second-order experimental design for 3 factors

\begin{tabular}{lcccc}
\hline Run $^{1}$ & Pressure $(\mathrm{MPa})$ & Chamber temperature $\left({ }^{\circ} \mathrm{C}\right)$ & Actual temperature $\left({ }^{\circ} \mathrm{C}\right)$ & Time $(\mathrm{min})$ \\
\hline US & 0.1 & 25 & 25 & 0 \\
1 & 200 & 25 & 26.45 & 10 \\
2 & 200 & 40 & 41.45 & 5 \\
3 & 200 & 40 & 41.45 & 15 \\
4 & 200 & 55 & 56.45 & 10 \\
5 & 400 & 25 & 27.90 & 5 \\
6 & 400 & 25 & 27.90 & 15 \\
$\mathrm{CP}$ & 400 & 40 & 42.90 & 10 \\
12 & 400 & 55 & 57.90 & 5 \\
13 & 400 & 55 & 57.90 & 15 \\
14 & 600 & 25 & 49.35 & 10 \\
15 & 600 & 40 & 44.35 & 5 \\
16 & 600 & 40 & 59.35 & 15 \\
17 & 600 & 55 & & 10 \\
\hline
\end{tabular}

${ }^{1} \mathrm{US}=$ untreated sample; $\mathrm{CP}=$ central point (includes runs 7, 8, 9, 10, and 11; i.e., this run was performed in quintuplicate).

${ }^{2}$ This is the temperature reached after pressurization; the increase over chamber temperature is due to adiabatic heat-up.

MG or A-state, which contains a significant amount of secondary structure and is relatively compact (Kuwajima, 1996; Demarest et al., 1999). In general, MG are less compact than the native protein but more compact than the denatured protein (Ashgari et al., 2004).

$\alpha$-Lactalbumin is more barostable than $\beta-\mathrm{LG}$, because no denaturation of $\alpha$-LA has been observed at pressures $<400 \mathrm{MPa}$, whereas $\beta$-LG denaturation starts at pressures around $100 \mathrm{MPa}$. The degree of denaturation of both proteins increases with pressure, HHP processing time, temperature, and $\mathrm{pH}$ (Huppertz et al., 2004).

Studies have been performed on the effect of HHP on the hydrophobicity, evaluated by the binding affinity for 8-anilino-1-naphthalene sulfonate (ANS), of $\beta$-LG (Yang et al., 2001) and whey protein concentrate ( $80 \%$ protein; Liu et al., 2005). Studies have also been performed to determine the effect of HHP on the functionality of $\beta$-LG (López-Fandiño, 2006a), $\alpha$-LA (Rodiles-López et al., 2008), whey protein concentrate, and whey protein isolate (Bouaouina et al., 2006; Krešić et al., 2006). However, little research has been done on the effect of HHP on the hydrophobicity and structure of $\alpha$-LA. The current work addresses these aspects and seeks to evaluate the effect of HHP on the denaturation temperature of $\alpha$-LA.

\section{MATERIALS AND METHODS}

\section{Protein Sample}

BioPURE $\alpha$-LA (batch JE 027-5-410) was kindly donated by Davisco Foods International Inc. (Eden Prairie, MN). The composition of the sample provided by the supplier was moisture content, $5.5 \%$; protein,
95\% (91\% of this protein corresponded to $\alpha-\mathrm{LA})$; fat, $0.5 \%$; carbohydrates, $0.5 \%$; and ash, $2.5 \%$.

\section{Experimental Design}

A Box-Behnken 3-level second-order experimental design for 3 factors was used to model the behavior of some of the parameters at the different $\mathrm{pH}$ values. The 3 independent variables were pressure, temperature, and holding time with levels of 200, 400, and $600 \mathrm{MPa}$; 25,40 , and $55^{\circ} \mathrm{C}$; and 5,10 , and 15 min, respectively. The design had 18 runs that included 5 replicates of the central point and an untreated sample $(\alpha-\mathrm{LA}$ in native state) as shown in Table 1 . The response variables were intrinsic fluorescence and surface hydrophobicity measured at 4 different $\mathrm{pH}$ values. All analyses were performed in triplicate and the mean value and the standard deviation calculated. Differences among samples were evaluated by one-way ANOVA. Modeling was performed with the aid of the Design Expert v.7 software (Stat-Ease Inc., Minneapolis, MN). One-way ANOVA was used to determine the significance of the models and to evaluate the significance of each of the terms in the equations.

\section{Methods}

High Pressure Treatment. The $\alpha$-LA at a concentration of $5 \%(\mathrm{wt} / \mathrm{vol})$ in distilled water was treated with HHP under the conditions of pressure, temperature, and holding time indicated by the software in a warm isostatic press with yoke (Engineered Pressure Systems Inc., Haverhill, MA) with a cylindrical pressure chamber (height $=0.255 \mathrm{~m}$, diameter $=0.10 \mathrm{~m}$ ). 
Water was used as the pressurizing fluid. The samples were equilibrated in the chamber for $5 \mathrm{~min}$ so that the process temperature could be reached. In this case, the come-up time $(4.5 \mathrm{~min})$ is the compression time required to reach $600 \mathrm{MPa}$. Pressure release time was $30 \mathrm{~s}$. After exposure to high pressure, the $\mathrm{pH}$ of the $\alpha$-LA solutions was measured and then the samples were freeze-dried and packed in sealed plastic bags. Freeze-drying was selected because it has been shown that this process does not produce significant changes in protein structure (Alvarez et al., 2007). Because the temperature increases around $0.72^{\circ} \mathrm{C}$ per $100 \mathrm{MPa}$ during pressurization, this increase due to pressurization is reported as actual temperature in Table 1.

$\boldsymbol{S D S}-\boldsymbol{P A} \boldsymbol{G E}$. The $\alpha$-LA samples were analyzed for possible molecular size changes (perhaps caused by HHP-induced aggregation) by SDS-PAGE according to the technique of Laemmli (1970). The SDS-PAGE was carried out on a slab gel with a 29:1 ratio of acrylamide to $N, N^{\prime}$-methylenebisacrylamide in an SDS-Tris-glycine discontinuous buffer system. Protein solutions (5 mg of protein $/ \mathrm{mL}$ ) were prepared in 4 phosphate $\mathrm{pH}$ buffer

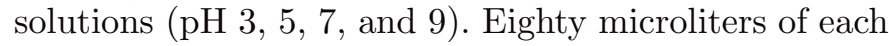
solution was mixed with $20 \mu \mathrm{L}$ of a nonreducing buffer solution (62.5 mM Tris-HCl, pH 6.8, 2\% SDS, and $0.05 \%$ bromophenol blue). Twenty microliters of this mixture was loaded onto the gel and the electrophoresis was performed at a constant current of $100 \mathrm{~mA}$ for $120 \mathrm{~min}$ in a Mini-V8.10 Vertical Gel Electrophoresis System (Gibco BRL Life Technologies, Gaithersburg, $\mathrm{MD})$. The gel was stained with $0.1 \%$ Coomassie Brilliant Blue in acetic acid:methanol:water (5:15:30) and destained with the same solvent without the dye. Each sample was analyzed in duplicate and compared with a low molecular weight calibration kit (Amersham Pharmacia Biotech, Piscataway, NJ). The prestained standards included phosphorylase b $(97 \mathrm{kDa})$, albumin (66 kDa), ovalbumin (45 kDa), carbonic anhydrase (30 $\mathrm{kDa})$, trypsin inhibitor (20.1 kDa), and $\alpha$-LA (14.4 $\mathrm{kDa})$.

Intrinsic Fluorescence. The conformational changes of $\alpha$-LA in solution were followed by intrinsic tryptophan fluorescence using an excitation wavelength of $292 \mathrm{~nm}$ and measuring the emission at a wavelength range of 300 to $400 \mathrm{~nm}$. The samples $(75 \mu \mathrm{L}$ of $0.2 \%$ protein solution in $0.1 \mathrm{M}$ phosphate buffer, $\mathrm{pH} 7$ ) were completed to a final 3-mL volume with the appropriate buffer $(\mathrm{pH} \mathrm{3,5,7}$, and 9) and put in $10 \times 10 \mathrm{~mm} \mathrm{cu-}$ vettes with controlled temperature $\left(25^{\circ} \mathrm{C}\right)$ and stirring. The measurements were made with a K2 Spectrofluorometer (ISS Inc., Champaign, IL).

Surface Hydrophobicity. The surface hydrophobicity of $\alpha$-LA was determined with the fluorescent hydrophobic probe 8-anilino-1-naphtalene sulfonate (ANS) according to Hayakawa and Nakai (1985). The ANS fluorescence of the samples $(0.2 \%$ protein solutions in 0.1 $M$ phosphate buffer, $\mathrm{pH} 7$ ) was assayed using an excitation wavelength of $380 \mathrm{~nm}$ and an emission wavelength in the range of 400 to $600 \mathrm{~nm}$. For the assay, $25 \mu \mathrm{L}$ of ANS (15 $\mathrm{m} M$ in $0.1 M$ phosphate buffer, $\mathrm{pH}$ 7) solution was added to $75 \mu \mathrm{L}$ of the sample, and completed to a final volume of $3 \mathrm{~mL}$ with an appropriate buffer $(\mathrm{pH}$ $3,5,7$, and 9). The measurements were made in $10 \times$ $10 \mathrm{~mm}$ cuvettes with a controlled temperature $\left(25^{\circ} \mathrm{C}\right)$ and stirring, by using the K2 spectrofluorometer. The surface hydrophobicity results were given in arbitrary units (a.u.) by the equipment software.

Circular Dichroism. It is well known that the circular dichroism (CD) spectrum of a protein is directly related to its secondary and tertiary structures (Hennessey and Johnson, 1981). The changes in secondary structure were monitored by measurement of the CD spectra over the range of 185 to $245 \mathrm{~nm}$ (far UV) in a J715 Spectropolarimeter (Jasco Inc., Easton, MD). The measurements were made in cuvettes with a $1-\mathrm{mm}$ pathlength at $25^{\circ} \mathrm{C}$ and filtered protein solutions of 0.15 $\mathrm{mg} / \mathrm{mL}$ in $0.05 M$ phosphate buffer at $\mathrm{pH} 3,5$, and 7 . The results were expressed as molar ellipticity (degree $\mathrm{cm}^{2} / \mathrm{dmol}$ ). The changes in tertiary structure were evaluated in the near UV range (250 to $320 \mathrm{~nm}$ ) in 1 $\mathrm{mg} / \mathrm{mL}$ protein solutions using cuvettes with a $10-\mathrm{mm}$ pathlength and buffers at $25^{\circ} \mathrm{C}$. For the near UV range, the study was performed with the untreated samples, the runs $1,4,5,9,13,14,17$, and the central point of the experimental design.

Thermostability Measurements. The CD measurements to evaluate thermostability were conducted in a J715 Spectropolarimeter equipped with a temperature-controlling unit (Jasco Inc.) as the temperature increased from 25 to $85^{\circ} \mathrm{C}$ and decreased again to $25^{\circ} \mathrm{C}$ at scan rates of $1^{\circ} \mathrm{C} / \mathrm{min}$. A concentration of $0.02 \mathrm{mg} /$ $\mathrm{mL}$ of $\alpha$-LA in $0.2 M$ phosphate buffer (for $\mathrm{pH}$ values of 3,5, and 7) was applied in these experiments. Molar ellipticity $\left(\theta\right.$; degrees $\left.\mathrm{cm}^{2} / \mathrm{mol}\right)$ was measured at 220 $\mathrm{nm}$ (Sim et al., 2009). From graphs of $\theta$ versus temperature, the value of the half-denaturing temperature (melting point, $\mathbf{T m}$ ) was calculated for the different $\mathrm{pH}$ values. In this case, the study was performed with the untreated sample, run $17\left(600 \mathrm{MPa}, 55^{\circ} \mathrm{C}, 10 \mathrm{~min}\right)$, and the central point of the experimental design (400 MPa, $\left.40^{\circ} \mathrm{C}, 10 \mathrm{~min}\right)$.

\section{RESULTS AND DISCUSSION}

Previous results (Rodiles-López et al., 2008) showed that under the conditions of time and temperature studied, HHP treatment created favorable $\mathrm{pH}$ conditions (6.6 to 6.8) that decreased the extent of dena- 
turation of $\alpha$-LA under pressure. The SDS-PAGE gels showed a main band with a molecular weight of 14 $\mathrm{kDa}$, which corresponded to monomeric $\alpha$-LA, in all the HHP-treated sample lanes. These results indicated that there were no changes in molecular size due to HHP-induced rupture, aggregation, or oligomerization. Thiol-disulfide interchanges among proteins contribute to the formation of aggregates and alter their functional properties (Swaisgood, 2005). In the case of $\alpha$-LA, there are no free thiol groups in the molecule and only a negligible fraction of the protein will form aggregates even at pressures as high as 1,000 $\mathrm{MPa}$, so thiol-induced oligomerization of this protein at HHP can only be achieved by the addition of low-molecular-weight reducing agents such as cysteine, 2-mercaptoethanol, or dithiothreitol (Jegouic et al., 1996).

\section{Intrinsic Fluorescence}

Proteins have natural or intrinsic fluorescence due to their aromatic amino acid residues (mainly tryptophan), which are usually in the interior of globular proteins because of their hydrophobic nature when in aqueous solution (Möller and Denicola, 2002). The natural or intrinsic fluorescence usually changes upon unfolding of the protein chain; however, it is difficult to predict how and to what degree the intensity of the fluorescence will change: it might increase or decrease. In the unfolded state of most proteins, tryptophan residues have a fluorescence emission maximum at around 350 to $355 \mathrm{~nm}$; however, when the protein is folded, with the tryptophan buried inside, this maximum shifts to around $330 \mathrm{~nm}$ or less (Royer, 1995). In the present study, the intrinsic fluorescence of $\alpha$-LA was studied at different values of $\mathrm{pH}$. In all cases, fluorescence intensity decreased slightly after the HHP treatments. The average intensity values of the untreated samples at $\mathrm{pH}$ $3,5,7$, and 9 were 40,586, 31,227, 32,997, and 32,329 a.u., respectively. The average intensity values of the HHP-treated samples at $\mathrm{pH}$ values of $3,5,7$ and 9 were $40,108,30,592,31,820$, and 30,241 a.u., respectively. We observed that the intensity values were $25 \%$ higher at $\mathrm{pH}$ 3. This is probably because of the exposure of hydrophobic residues in the molten globule state. A similar reversible decrease in fluorescence intensity was observed by Dufour et al. (1994) in the case of $\beta$-LG at acid $\mathrm{pH}$. At $\mathrm{pH} 3$, no significant changes $(P \leq$ $0.05)$ were observed in the values of maximum emission wavelength (MEW) for the different HHP treatments (including the untreated sample) of $\alpha$-LA solutions (Table 2). The untreated sample had an MEW of 336 $\mathrm{nm}$, and the average of the 17 HHP-treated samples had an MEW of $332.5 \pm 1.7$. Again, these results are similar to those obtained by Dufour et al. (1994) for $\beta$-LG, indicating very little HHP-related unfolding at this $\mathrm{pH}$. This lack of response to HHP could be because $\alpha$-LA exists as a stable MG at acidic pH (Kobashigawa et al., 1999). The average MEW for the untreated and HHP-treated samples at the other $\mathrm{pH}$ values $(5,7$, and 9) were $322.3 \pm 0.6$ and $325.8 \pm 2.0 \mathrm{~nm}$, respectively. This indicates average red shifts of 13.7 and $6.7 \mathrm{~nm}$, respectively, for the untreated and HHP-treated samples, when the $\mathrm{pH}$ is lowered to 3 , which are consistent with exposure of previously buried tryptophan residues to water and their resulting hydration, which occurs during the partial unfolding process of formation of a molten globule. At pH 5, the average MEW for the untreated and HHP-treated samples were 323 and 325.8 $\pm 1.3 \mathrm{~nm}$, respectively. The MEW for the most severe treatment $\left(600 \mathrm{MPa}, 55^{\circ} \mathrm{C}, 10 \mathrm{~min}\right)$ was 328 , showing a red shift of $5 \mathrm{~nm}$ due to the HHP treatment (see Table 2 ). When the software was used to model the behavior at this $\mathrm{pH}$, the following second-order equation was obtained:

$$
\begin{gathered}
\text { MEW }(\mathrm{pH} 5)=318.39-0.01 \mathrm{P}+0.264 \mathrm{~T}+0.523 \mathrm{t} \\
+0.0001625 \mathrm{PT}+0.000475 \mathrm{Pt}-0.00318 \mathrm{~T}^{2},
\end{gathered}
$$

where $\mathbf{P}, \mathbf{T}$, and $\mathbf{t}$ are the pressure, temperature, and time of processing, respectively. The determination coefficient $\mathrm{R}^{2}$ was 0.94 . The model indicated that at this $\mathrm{pH}$, which is very near the isoelectric point of the protein (4.2-4.5), all variables and the interactions of pressure with the other 2 variables were significant for the shift in MEW. A similar behavior was observed at pH 7 (the natural pH of the protein solution); however, in this case, the average MEW for the untreated and HHP-treated samples were 322 and $325.5 \pm 2 \mathrm{~nm}$, respectively. The MEW for the most severe treatment $\left(600 \mathrm{MPa}, 55^{\circ} \mathrm{C}, 10 \mathrm{~min}\right)$ was also 328 , with a red shift of $6 \mathrm{~nm}$ caused by the HHP treatment (Table 2). The model was lineal with an $\mathrm{R}^{2}=0.85$ :

MEW $(\mathrm{pH} 7)=317.98+0.0036 \mathrm{P}+0.115 \mathrm{~T}+0.168 \mathrm{t}$.

These results are in partial agreement with the data obtained by Tanaka et al. (1996), who found that the intrinsic fluorescence spectra of $\alpha$-LA scarcely changed in intensity or MEW with pressures up to $400 \mathrm{MPa}$.

At $\mathrm{pH} 9$, the average MEW for the untreated and HHP-treated samples were 322 and $326.1 \pm 2.6 \mathrm{~nm}$, respectively. The MEW for the most severe treatment $\left(600 \mathrm{MPa}, 55^{\circ} \mathrm{C}, 10 \mathrm{~min}\right)$ was 332 , showing a red shift of $10 \mathrm{~nm}$ caused by the HHP treatment. Pressure was 
Table 2. Intrinsic and extrinsic fluorescence for the different processing conditions at $4 \mathrm{pH}$ values ${ }^{1}$

\begin{tabular}{|c|c|c|c|c|c|c|c|c|}
\hline Run $^{2}$ & \multicolumn{2}{|c|}{$\mathrm{pH} 3$} & \multicolumn{2}{|c|}{ pH 5} & \multicolumn{2}{|c|}{ pH 7} & \multicolumn{2}{|c|}{ pH 9} \\
\hline US & 336 & 30,929 & 323 & 2,486 & 322 & 1,700 & 322 & 1,817 \\
\hline 2 & 333 & 31,904 & 326 & 2,953 & 324 & 1,834 & 326 & 2,054 \\
\hline 3 & 331 & 31,640 & 326 & 3,328 & 325 & 2,452 & 327 & 1,940 \\
\hline 4 & 331 & 32,521 & 326 & 5,636 & 326 & 3.556 & 328 & 3,032 \\
\hline 12 & 336 & 32,002 & 326 & 6,500 & 326 & 3,702 & 327 & 3,318 \\
\hline 13 & 334 & 33,397 & 327 & 7,332 & 329 & 4,900 & 328 & 4,154 \\
\hline 14 & 331 & 27,177 & 325 & 3,821 & 324 & 2,801 & 324 & 2,162 \\
\hline 15 & 331 & 31,365 & 325 & 4,470 & 325 & 2,863 & 324 & 2,714 \\
\hline 16 & 331 & 31,848 & 327 & 6,142 & 328 & 3,880 & 326 & 3,126 \\
\hline 17 & 331 & 33,590 & 328 & 9,531 & 328 & 6,095 & 332 & 4,978 \\
\hline
\end{tabular}

${ }^{1}$ IFMEW = intrinsic fluorescence maximum emission wavelength; $\mathrm{SH}=$ surface hydrophobicity (extrinsic 8-anilino-1-naphthalene sulfonate fluorescence); a.u. = arbitrary units.

${ }^{2} \mathrm{US}=$ untreated sample; $\mathrm{CP}=$ central point (includes runs 7, 8, 9, 10, and 11; i.e., this run was performed in quintuplicate).

not a significant variable and the model was also lineal with an $\mathrm{R}^{2}=0.76$ :

$$
\operatorname{MEW}(\mathrm{pH} 9)=317.59+0.164 \mathrm{~T}+0.185 \mathrm{t} .
$$

In this case, the higher the temperature and the longer the time, the greater the red shift in MEW.

\section{Surface Hydrophobicity}

The ANS probe is widely used to assay hydrophobicity of proteins because it is practically nonfluorescent in water but its emission increases significantly in hydrophobic environments (Möller and Denicola, 2002). When the protein molecule unfolds as a result of thermal or HHP processes, an increase in its surface hydrophobicity (detected as extrinsic ANS fluorescence) is expected (Sava et al., 2005). The ANS fluorescence intensity at $\mathrm{pH} 3$ was almost 20 times that at other $\mathrm{pH}$ values. This result corroborates the presence of an $\mathrm{MG}$ at this acid $\mathrm{pH}$, because the residues in the hydrophobic core of the MG are accessible to ANS, greatly increasing the extrinsic fluorescence (Van der Heeren et al., 1998). Increased exposure of some of the 4 tryptophan residues is responsible for the increase in hydrophobic surface in the MG state of $\alpha$-LA (Lala and Kaul, 1992). The ANS fluorescence values for the untreated and HHP-treated samples at $\mathrm{pH} 3$ are given in Table 2. No significant model could be built from the results at this low $\mathrm{pH}$ MG state. The average surface hydrophobicity for the untreated and HHP-treated samples were 30,929 and $31,897 \pm 1,711$ a.u., respectively, and no effect on any of the process variables could be detected.
At the other $\mathrm{pH}$ values (5, 7, and 9), a definite increase in surface hydrophobicity with increasing severity of the treatment could be observed (Table 2). The largest increase in fluorescence was observed at $\mathrm{pH} 5$; that is, near the isoelectric point. The quadratic model that best described this behavior, with $\mathrm{R}^{2}=0.97$, was

$$
\begin{gathered}
\mathrm{SH}(\mathrm{pH} 5)=8,491.95-2.69 \mathrm{P}-353.22 \mathrm{~T}-194.43 \mathrm{t} \\
+0.216 \mathrm{PT}+6.04 \mathrm{Tt}+4.34 \mathrm{~T}^{2},
\end{gathered}
$$

where $\mathrm{SH}$ is surface hydrophobicity.

Different quadratic models were used for a better fit at $\mathrm{pH} 7$ and 9 . Both models have $\mathrm{R}^{2}$ values of 0.97 :

$$
\begin{gathered}
\mathrm{SH}(\mathrm{pH} 7)=5,217.7-5.39 \mathrm{P}-208.15 \mathrm{~T}-22.74 \mathrm{t} \\
+0.123 \mathrm{PT}+2.6 \mathrm{Tt}+0.00533 \mathrm{P}^{2} \\
\mathrm{SH}(\mathrm{pH} 9)=4,563.22-4.03 \mathrm{P}-162.81 \mathrm{~T}+31.65 \mathrm{t} \\
+0.16 \mathrm{PT}+1.993 \mathrm{~T}^{2} .
\end{gathered}
$$

In all 3 models, all of the process variables affected the response, and some interaction among them is present. Increases in the ANS fluorescence of $\alpha$-LA were also observed by Tanaka et al. (1996) when the processing pressures were $>200 \mathrm{MPa}$. Temperature is also an important factor for the increase in surface hydrophobicity. Sava et al. (2005) observed a marked increase in ANS fluorescence when $\beta$-LG at $\mathrm{pH} 7.5$ was heated to $67.5^{\circ} \mathrm{C}$ and beyond. In this study, the same behavior was observed for $\alpha$-LA at lower temperatures and at $\mathrm{pH}$ values of 5,7 , and 9 (see runs 1 and 4 in Table 2 in which the processing pressure and time are constant). 


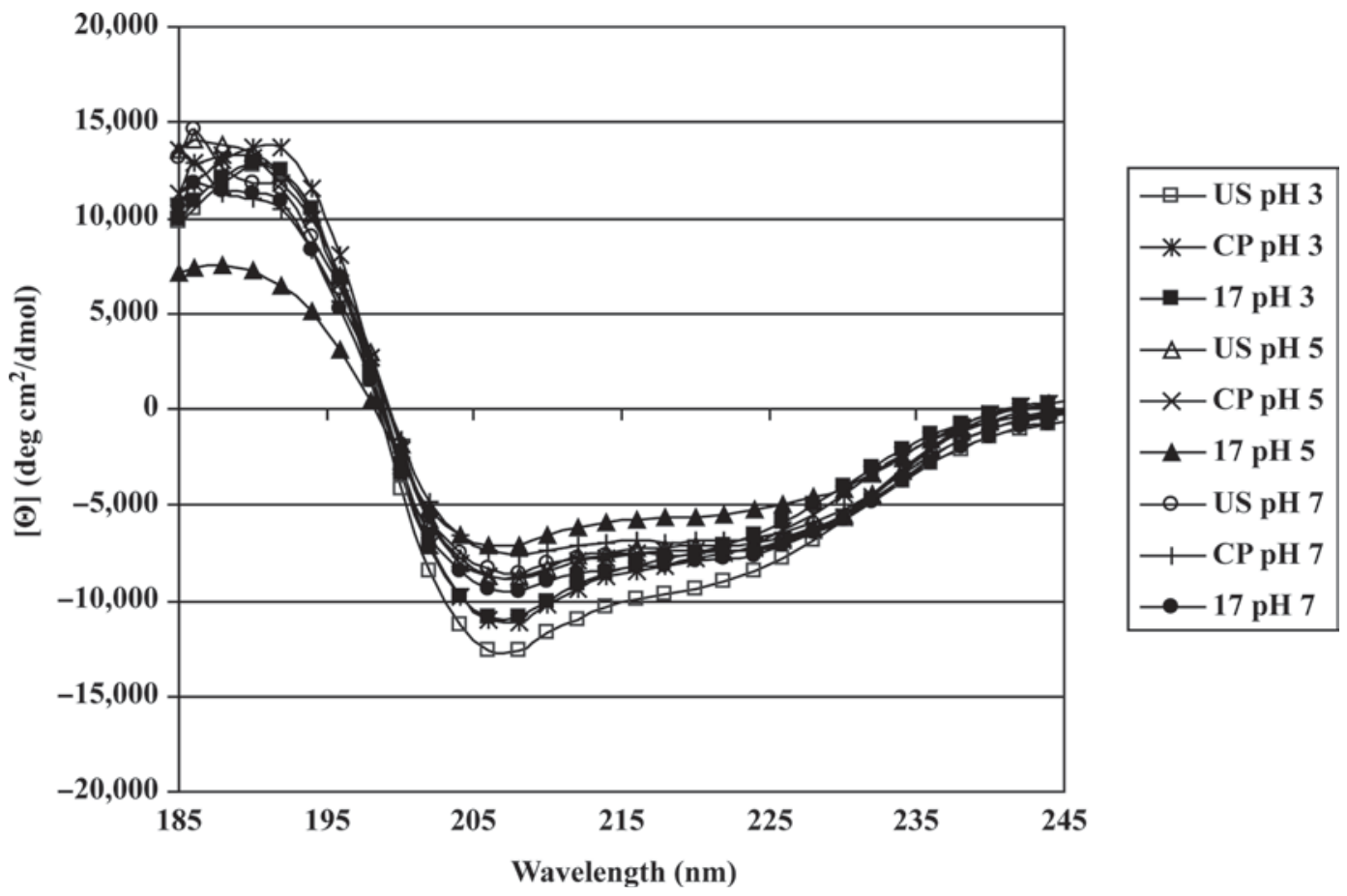

Figure 1. Far-UV circular dichroism spectra for the untreated $\alpha$-LA (US), central point (CP; $\left.400 \mathrm{MPa}, 40^{\circ} \mathrm{C}, 10 \mathrm{~min}\right)$, and condition 17 $\left(600 \mathrm{MPa}, 55^{\circ} \mathrm{C}, 10 \mathrm{~min}\right)$ at $\mathrm{pH} 3,5$, and 7 .

Additionally, positive interactions between pressure and temperature were present in the 3 models, indicating a possible synergistic behavior of these 2 process variables.

The MEW values were constant and, in all cases, independent of the HHP treatment for every $\mathrm{pH}$ at which the wavelength was measured. The MEW values

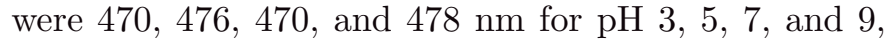
respectively.

\section{Far-UV CD}

Far-UV ellipticity results mainly from peptide groups fixed by the secondary protein structure. The native form of $\alpha$-LA has negative ellipticity in the far-UV spectrum, with a minimum at $208 \mathrm{~nm}$ (Kuwajima et al., 1985). The spectra for the untreated protein, the central point $\left(400 \mathrm{MPa}, 40^{\circ} \mathrm{C}, 10 \mathrm{~min}\right)$, and the most severe treatment $\left(600 \mathrm{MPa}, 55^{\circ} \mathrm{C}, 10 \mathrm{~min}\right)$ at each of the assayed $\mathrm{pH}$ values $(3,5$, and 7$)$ are shown in Figure 1. All the spectra are very similar and show the typical minimum at $208 \mathrm{~nm}$. Because no differences were apparent, the contents of $\alpha$-helix, $\beta$-strand, and random structure were calculated from the CD data by means of the k2d algorithm (Andrade et al., 1993).

The changes in secondary structure are shown for the central point and the most severe condition (600 MPa, $55^{\circ} \mathrm{C}, 10 \mathrm{~min}$ ) in Table 3. The data for the untreated sample at $\mathrm{pH} 7$ are consistent with the information obtained by Robbins and Holmes (1970; 25-26\% $\alpha$-helix, $14-15 \% \beta$-structure, and $60 \%$ random structure). There were no evident changes in secondary structure at this $\mathrm{pH}$ as the severity of the treatment increased. This result is in agreement with the results of Hosseini-nia et al. (2002), who found that $\alpha-\mathrm{LA}$ at $\mathrm{pH} 7$ showed extensive resistance to high pressure (up to 1,270 MPa) with no major structural changes. They also reported that, at $\mathrm{pH} 7$, BSA showed minimal irreversible secondary structural changes with pressure, showing a minor loss of $\beta$-sheet structure in favor of $\alpha$-helix. The behavior of $\beta-\mathrm{LG}$ is similar to that of BSA, showing an increase in $\alpha$-helix content at $\mathrm{pH} 7$ as the intensity of the HHP/temperature treatment increased (Aouzelleg et al., 2004). At pH 3, a slight decrease in the $\alpha$-helix content concomitant with an increase in $\beta$-sheet content was observed as the severity of the treatment increased. This could mean that the capacity of $\alpha$-LA to form low-pH MG with similar secondary structure is not significantly altered by HHP treatment. We also observed that the untreated sample at $\mathrm{pH} 3$ had a native-like secondary structure very similar to the untreated sample at $\mathrm{pH} 7$ as reported by Kuwajima (1996). At $\mathrm{pH} 5$ (near the isoelectric point), there was a clear decrease $(37.5 \%)$ in the $\alpha$-helix content concomitant with a high increase in $\beta$-strand content (53\%) for the most severe processing condition. The ellipticity value at $208 \mathrm{~nm}$ 
Table 3. Changes in secondary structure of $\alpha$-LA under different processing conditions and $3 \mathrm{pH}$ values

\begin{tabular}{lcccc}
\hline Run $^{1}$ & $\mathrm{pH}$ & $\alpha$-helix & $\beta$-strand & Random structure \\
\hline US & 3 & 0.28 & 0.16 & 0.56 \\
CP & 3 & 0.24 & 0.24 & 0.53 \\
17 & 3 & 0.22 & 0.26 & 0.53 \\
US & 5 & 0.24 & 0.19 & 0.57 \\
CP & 5 & 0.24 & 0.18 & 0.57 \\
17 & 5 & 0.15 & 0.29 & 0.56 \\
US & 7 & 0.26 & 0.17 & 0.58 \\
CP & 7 & 0.25 & 0.18 & 0.58 \\
17 & 7 & 0.26 & 0.16 & 0.58 \\
\hline
\end{tabular}

${ }^{1} \mathrm{US}=$ untreated sample; $\mathrm{CP}=$ central point $\left(400 \mathrm{MPa}, 40^{\circ} \mathrm{C}, 10 \mathrm{~min}\right)$; $17=$ condition $17\left(600 \mathrm{MPa}, 55^{\circ} \mathrm{C}, 10 \mathrm{~min}\right)$.

for this condition was slightly higher compared with all the other treatments. A direct temperature dependence of the ellipticity at $220 \mathrm{~nm}$ has been observed at $\mathrm{pH} 7.5$ for this same protein (Van der Heeren and Hanssens, 1994).

\section{Near-UV CD}

Near-UV ellipticity results mainly from aromatic groups (mainly tryptophan) and cystine residues fixed by the tertiary protein structure (Robbins and Holmes, 1970). The native form of $\alpha$-LA has negative ellipticity in the near-UV spectrum, with a minimum at 270 nm (Van der Heeren and Hanssens, 1994). The spectra for the untreated protein, the central point (400 MPa, $40^{\circ} \mathrm{C}, 10 \mathrm{~min}$ ), and the most severe treatment (600 MPa, $\left.55^{\circ} \mathrm{C}, 10 \mathrm{~min}\right)$ at each of the assayed $\mathrm{pH}$ values $(3,5$, and 7) are shown in Figure 2. At $\mathrm{pH} 3$, the spectra for the 3 assayed conditions are identical and showed the disappearance of the $270 \mathrm{~nm}$ peak, indicating a loss of the specific tertiary structure of the aromatic side chains. This is consistent with the formation of a low-pH MG (Kuwajima et al., 1985). The peak size diminished in intensity progressively as the severity of the treatment increased, indicating the gradual loss of tertiary structure. Orlien et al. (2007) reported that the pressure-induced penetration of water into the interior of a protein likely leads to loss of tertiary structure to take on the conformation of an MG. Previous results have indicated that the interior of the MG of $\alpha-\mathrm{LA}$ is, effectively, highly hydrated (Kobashigawa et al., 1999). Alvarez et al. (2007) could not detect changes in the tertiary structure of $\alpha$-LA by electrospray ionization mass spectrometry; however, the conditions of the HHP were different $\left(450,550\right.$, and $650 \mathrm{MPa}, 10^{\circ} \mathrm{C}$, and $15 \% \mathrm{wt} / \mathrm{vol}$ protein solutions). Hence, from the results shown in Table 3 and Figure 2, it can be said that the $\mathrm{CD}$ technique allowed the identification of a wide range of structures differing from the native protein and with the characteristics typical of the MG state, which re- sulted from the combined effect of HHP, temperature, and processing time. These results are additional proof that $\alpha$-LA is much more resistant to denaturation under HHP and moderate temperatures compared with $\beta$-LG.

\section{Thermostability}

All the samples showed higher thermostability (higher Tm values) as the $\mathrm{pH}$ went from 7 to 3 (See Table 4). Thermostability also increased as the severity of the treatment increased, possibly indicating the generation of a more thermostable structure because of the effect of HHP treatment. The more thermostable product was obtained at $600 \mathrm{MPa}$ and $55^{\circ} \mathrm{C}$ for $10 \mathrm{~min}$ at $\mathrm{pH} 3$, with a Tm value of $70.41^{\circ} \mathrm{C}$. Messens et al. (1997) indicate that when pressure increases to $100 \mathrm{MPa}$, the denaturation temperature of the protein also increases, whereas at higher pressure values, the temperature of denaturation generally decreases. This last phenomenon could only be observed at $\mathrm{pH} 5$, because at $\mathrm{pH}$ values of 3 and 7 , the Tm continued to increase with pressure. It has been observed that at low protein concentrations the structural transition can be reversible in thermal scans conducted at a rate greater than $1^{\circ} \mathrm{C} / \mathrm{min}$ (BenítezCardoza et al., 2001). Under these conditions, however, the denaturation-renaturation cycle exhibited marked hysteresis, which results in differences between the $\mathrm{Tm}$ values determined during the denaturation and renaturation cycles. This explains the differences between these values for $\alpha$-LA shown in Table 4 .

More experiments must be performed, but these results could indicate that more stable structures could be produced from HHP-treated $\alpha$-LA. It has previously been shown that HHP processing has a positive effect on many functional properties (Rodiles-López et al., 2008), but our study shows that this effect has been achieved through the formation of more thermostable structures that can be used advantageously in foods.

Table 4. Denaturation temperatures (Tm) of $\alpha$-LA for 3 different processing conditions at $3 \mathrm{pH}$ values determined during denaturation (Tm1) and renaturation (Tm2)

\begin{tabular}{lcll}
\hline Run $^{1}$ & $\mathrm{pH}$ & $\mathrm{Tm} 1$ & $\mathrm{Tm} 2$ \\
\hline US & 3 & 61.97 & 61.77 \\
CP & 3 & 66.98 & 59.22 \\
17 & 3 & 70.41 & 55.99 \\
US & 5 & 56.40 & 57.67 \\
CP & 5 & 52.40 & 56.58 \\
17 & 5 & 54.52 & 54.45 \\
US & 7 & 53.12 & 55.66 \\
CP & 7 & 53.80 & 56.99 \\
17 & 7 & 55.43 & 59.60 \\
\hline
\end{tabular}

${ }^{1} \mathrm{US}=$ untreated sample; $\mathrm{CP}=$ central point $\left(400 \mathrm{MPa}, 40^{\circ} \mathrm{C}, 10 \mathrm{~min}\right)$; $17=$ condition $17\left(600 \mathrm{MPa}, 55^{\circ} \mathrm{C}, 10 \mathrm{~min}\right)$. 


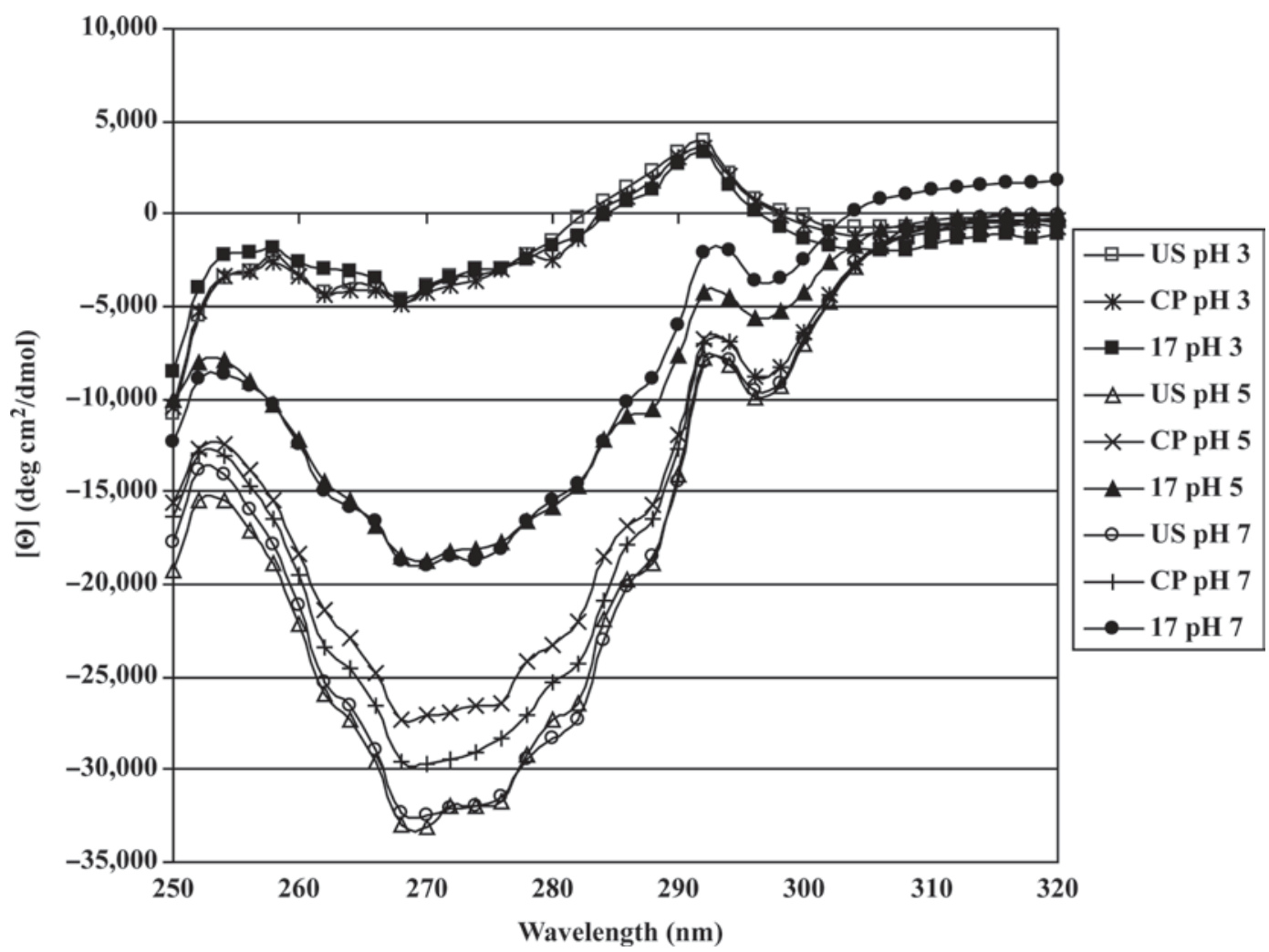

Figure 2. Near-UV circular dichroism spectra for the untreated $\alpha$-LA (US), central point (CP; $\left.400 \mathrm{MPa}, 40^{\circ} \mathrm{C}, 10 \mathrm{~min}\right)$, and condition 17 $\left(600 \mathrm{MPa}, 55^{\circ} \mathrm{C}, 10 \mathrm{~min}\right)$ at $\mathrm{pH} 3,5$, and 7 .

There are other approaches such as the use of preheating and sonication to increase the heat stability of whey proteins (Ashokkumar et al., 2009); however, in this case, the simultaneous improvement in functional properties could bring great benefit to the dairy industry.

\section{CONCLUSIONS}

The different HHP processes to which $\alpha$-LA was subjected in this work resulted in a wide range of molten globules with increased thermostability and with differences in their surface hydrophobicity and at the secondary and tertiary structure levels. Because most of the changes in protein structure are related to modifications in functional properties, this study suggests that the use of combined high pressure-temperature processes to obtain molten globule structures with different functional properties at different $\mathrm{pH}$ values is feasible.

\section{ACKNOWLEDGMENTS}

This work was partially financed by the Instituto Politécnico Nacional (Mexico City, Mexico). Octavio Rodiles-López and Izlia J. Maya Arroyo thank the Con- sejo Nacional de Ciencia y Tecnología (Mexico City, Mexico) for the awarding of their scholarship. Authors Jaramillo-Flores, Gutiérrez-López, and Hernández-Sánchez also acknowledge the fellowship from COFAA-IPN (Mexico City, Mexico).

\section{REFERENCES}

Alvarez, P. A., H. S. Ramaswamy, and A. A. Ismail. 2007. Effect of high-pressure treatment on the electrospray ionization mass spectrometry (ESI-MS) profiles of whey proteins. Int. Dairy J. 17:881-888.

Andrade, M. A., P. Chacón, J. J. Merelo, and F. Morán. 1993. Evaluation of secondary structure of proteins from UV circular dichroism using an unsupervised learning neural network. Protein Eng. 6:383-390.

Aouzelleg, A., L. A. Bull, N. C. Price, and S. M. Kelly. 2004. Molecular studies of pressure/temperature-induced structural changes in bovine $\beta$-lactoglobulin. J. Sci. Food Agric. 84:398-404.

Ashgari, M. S., K. Khajeh, F. Morodian, B. Ranjbar, and H. NaderiManesh. 2004. Acid-induced conformational changes in Bacillus amyloliquefaciens $\alpha$-amylase: Appearance of a molten globule like state. Enzyme Microb. Technol. 35:51-57.

Ashokkumar, M., J. Lee, B. Zisu, R. Bhaskarcharya, M. Palmer, and S. Kentish. 2009. Sonication increases the heat stability of whey proteins. J. Dairy Sci. 92:5353-5356.

Balny, C., and P. Masson. 1993. Effect of high pressures on proteins. Food Rev. Int. 9:611-628.

Benítez-Cardoza, C. G., A. Rojo-Domínguez, and A. HernándezArana. 2001. Temperature-induced denaturation and renaturation of triosephosphate isomerase from Saccharomyces cerevisiae: 
Evidence of dimerization coupled to refolding of the thermally unfolded protein. Biochemistry 40:9049-9058.

Bouaouina, H., A. Desrumaux, C. Loisel, and J. Legrand. 2006. Functional properties of whey proteins as affected by dynamic high-pressure treatment. Int. Dairy J. 16:275-284.

Demarest, S. J., J. A. Boice, R. Fairman, and D. Raleigh. 1999. Defining the core structure of the $\alpha$-lactalbumin molten globule state. J. Mol. Biol. 294:213-221.

Devlieghere, F., L. Vermeiren, and J. Debevere. 2004. New preservation technologies: Possibilities and limitations. Int. Dairy J. 14:273285.

Dufour, E., G. H. B. Hoa, and T. Haertlé. 1994. High-pressure effects on $\beta$-lactoglobulin interactions with ligands studied by fluorescence. Biochim. Biophys. Acta 1206:166-172.

Farrell, H. M., R. Jimenez-Flores, G. T. Bleck, E. M. Brown, J. E Butler, L. K. Creamer, C. L. Hicks, C. M. Hollar, K. F. Ng-KwaiHang, and H. E. Swaisgood. 2004. Nomenclature of the proteins of cows' milk-Sixth revision. J. Dairy Sci. 87:1641-1674.

Hayakawa, S., and S. Nakai. 1985. Relationships of hydrophobicity and net charge to the solubility of milk and soy protein. J. Food Sci. 50:486-491.

Hennessey, J. P., and W. C. Johnson. 1981. Information content in the circular dichroism of proteins. Biochemistry 20:1085-1094.

Hogan, E., A. L. Kelly, and D. W. Sun. 2005. High-pressure processing of foods: An overview. Pages 1-31 in Emerging Technologies for Food Processing. D. W. Sun. ed. Elsevier Academic Press, San Diego, CA.

Hosseini-nia, T., A. A. Ismail, and S. Kubow. 2002. Effect of high hydrostatic pressure on the secondary structures of BSA and apoand holo- $\alpha$-lactalbumin employing Fourier transform infrared spectroscopy. J. Food Sci. 67:1341-1347.

Huppertz, T., P. F. Fox, and A. L. Kelly. 2004. High pressure treatment of bovine milk: Effects on casein micelles and whey proteins. J. Dairy Res. 71:97-106.

Jegouic, M., V. Y. Grinberg, A. Guingant, and T. Haertlé. 1996. Thioinduced oligomerization of alpha-lactalbumin at high pressure. J. Protein Chem. 15:501-509.

Kobashigawa, Y., M. Sakurai, and K. Nitta. 1999. Effect of hydrostatic pressure on unfolding of $\alpha$-lactalbumin: Volumetric equivalence of the molten globule and unfolded state. Protein Sci. 8:27652772 .

Krešić, G., V. Lelas, Z. Herceg, and A. Režek. 2006. Effects of high pressure on functionality of whey protein concentrate and whey protein isolate. Lait 86:303-315.

Kuwajima, K. 1996. The molten globule state of $\alpha$-lactalbumin. FASEB J. 10:102-109.

Kuwajima, K., Y. Hiraoka, M. Ikeguchi, and S. Sugai. 1985. Comparison of the transient folding intermediates in lysozyme and $\alpha$-lactalbumin. Biochemistry 24:874-881.

Laemmli, U. K. 1970. Cleavage of structural proteins during the assembly of the head of bacteriophage T4. Nature 227:680-685.

Lala, A. K., and P. Kaul. 1992. Increased exposure of hydrophobic surface in molten globule state of $\alpha$-lactalbumin. J. Biol. Chem. 267:19914-19918

Liu, X., J. R. Powers, B. G. Swanson, H. H. Hill, and S. Clark. 2005. Modification of whey protein concentrate hydrophobicity by high hydrostatic pressure. Innov. Food Sci. Emerg. 6:310-317.
López-Fandiño, R. 2006. High pressure-induced changes in milk proteins and possible applications in dairy technology. Int. Dairy J. 16:1119-1131.

López-Fandiño, R. 2006a. Functional improvement of milk whey proteins induced by high hydrostatic pressure. Crit. Rev. Food Sci. Nutr. 46:351-363.

Messens, W., J. Van Camp, and A. Huyghebaert. 1997. The use of high pressure to modify functionality of food proteins. Trends Food Sci. Technol. 8:107-112.

Möller, M., and A. Denicola. 2002. Study of protein-ligand binding by fluorescence. Biochem. Mol. Biol. Educ. 30:309-312.

Nabhan, M. A., J. M. Girardot, S. Campagna, J. L. Gaillard, and Y. Le Roux. 2004. Isolation and characterization of copolymers of $\beta$-lactoglobulin, $\alpha$-lactalbumin, $\kappa$-casein and $\alpha_{\mathrm{s} 1}$-casein generated by pressurization and thermal treatment of raw milk. J. Dairy Sci. 87:3614-3622.

Orlien, V., K. Olsen, and L. H. Skibsted. 2007. In situ measurements of $\mathrm{pH}$ changes in $\beta$-lactoglobulin solutions under high hydrostatic pressure. J. Agric. Food Chem. 55:4422-4428.

Rastogi, N. K. S. M. S. Raghavarao, V. M. Balasubramaniam, K. Niranjan, and D. Knorr. 2007. Opportunities and challenges in high pressure processing of foods. Crit. Rev. Food Sci. Nutr. 47:69-112.

Robbins, F.M., and L.G. Holmes. 1970. Circular dichroism spectra of $\alpha$-lactalbumin. Biochim. Biophys. Acta Protein Struct. M 221:234-240.

Rodiles-López, J. O., M. E. Jaramillo-Flores, G. F. Gutiérrez-López, A Hernández-Arana, R. E. Fosado-Quiroz, G. V. Barbosa-Cánovas, and H. Hernández-Sánchez. 2008. Effect of high hydrostatic pressure on bovine $\alpha$-lactalbumin functional properties. J. Food Eng. 87:363-370.

Royer, C. A. 1995. Approaches to teaching fluorescence spectroscopy. Biophys. J. 68:1191-1195.

Sava, N., I. Van der Plancken, W. Claeys, and M. Hendrickx. 2005. The kinetics of heat-induced structural changes of $\beta$-lactoglobulin. J. Dairy Sci. 88:1646-1653.

Sim, D. W., Y. S. Lee, J. H. Kim, M. D. Seo, B. J. Lee, and H. S. Won. 2009. HP0902 from Helicobacter pylori is a thermostable, dimeric protein belonging to an all- $\beta$ topology of the cupin superfamily Biochem. Mol. Biol. Rep. 42:387-392.

Swaisgood, H. E. 2005. The importance of disulfide bridging Biotechnol. Adv. 23:71-73.

Tanaka, N., K. Nakajima, and S. Kunugi. 1996. The pressureinduced structural change of bovine $\alpha$-lactalbumin as studied by a fluorescence hydrophobic probe. Int. J. Pept. Protein Res. 48:259-264.

Vanderheeren, G., and I. Hanssens. 1994. Thermal unfolding of bovine Q-lactalbumin. J. Biol. Chem. 269:7090-7094.

Vanderheeren, G., I. Hanssens, K. Noyelle, H. Van Dael, and M. Joniau. 1998. The perturbations of the native state of goat $\alpha$-lactalbumin induced by $1,1^{\prime}$-bis(4-anilino-5-naphtalenesulfonate) are $\mathrm{Ca}^{2+}$ dependent. Biophys. J. 75:2195-2204.

Yang, J., A. Dunker, J. R. Powers, S. Clark, and B. G. Swanson. 2001. $\beta$-Lactoglobulin molten globule induced by high pressure. J. Agric. Food Chem. 49:3236-3243. 